AVRASYA Uluslararası Araştırmalar Dergisi Cilt:5 •Sayı:12•Özel Sayı 2017•Türkiye

\title{
KIPCHAKS IN THE MIDDLE EAST FROM AN-NASIR MUHAMMAD TO BARQUK
}

Doç. Dr. Yaroslav PYLYPCHUK*

\begin{abstract}
This article is devoted to the history of the Kypchak sultans and emirs in the Middle East in 1310-1382. Having come to power, an-Nasir Muhammad took up the reorganization of the power vertical in 1310-1316. Amirs involved in the troubles of 1293-1310. Were either physically eliminated or fled to neighboring states. Amirs of the era of Kalawun were replaced by the henchmen of al-Nasir Muhammad. Periodically, the sultan repressed the over-amplified emirs. The Sultan expanded enriched his country by trading with Europeans and by conducting financial affairs by the Copts. Some privileges went to the Bedouin Arabs and Turkmans. In foreign policy, an-Nasir Muhammad moved from defense to expansion. The invasion of Syria in 1312 year was unsuccessful and soon the Hulaguids went to peace with the Mamluks. This is made unnecessary alliance with the Golden Horde. Relations with the Juchids from an-Nasir Muhammad were cool. At the same time, the Mamluks did not consider it shameful to support and let not the direct opponents of the Hulaguids - the governor Timurtash and the Georgian king Giorgi V Brilliant. The favorite targets for the Mamluks raids were Cilicia Armenia and Nubia. Under An-Nasir Muhammad, a number of campaigns against Cilicia were carried out. After his death, they temporarily stopped because of the internal struggle in the Mamluksom Sultanate. The attacks of Cypriots and Venetians on the Middle Eastern coastline in the 60 -ies of XIV century. Revealed the weakness of the power of the Turkic sultans and amirs in Egypt and Syria. After al-Nasir Muhammad, they could defeat the frankly weak Cilicia Armenia. Certain amirs managed to seize power only for a short time. The most prominent amirs of this time were Kavsun, Yalbuga, Shaykhun, Sargitmish. Arab Bedouin tribes periodically rebelled in Syria and Egypt ggainst the power of the Mamluks,. It should be noted that in the struggle between themselves the Turkic emirs did not disdain to use the help of the Burji amirs, just as Barquk did not disdain to use the help of the Turkic emirs. However, it is worth noting that since 1382, in the history of the Mamluk Sultanate, a new period in history began, when the Circassian dynasty began to rule Egypt and Syria.
\end{abstract}

Keywords: Kipchaks, Al-Nasir Muhammad, Mamluks, Emirs, Barquk, Circassians.

\section{КЫПЧАКИ НА БЛИЖНЕМ ВОСТОКЕ ОТ АН-НАСИРА МУХАММЕДА ДО БАРКУКА}

\section{PEЗЮME}

Данная статья посвященна истории кыпчакских султанов и эмиров на Ближнем Востоке в 1310-1382 гг. Прийдя к власти ан-Насир Мухаммед занялся перестройкой властной вертикали в 1310-1316 гг. Эмиры замешаные в смуте 1293-1310 гг. были или физически устранены или бежали в сопредельные государства. Эмиры эпохи Калавуна были заменены ставленниками ан-Насира Мухаммеда. Периодически султан репрессировал чрезмернно усилявшихся эмиров. Султан расширял обогащал свою страну за счет торговли с европейцами и за счет ведения финансовых дел коптами. Некоторые привилегии достались и арабам-бедуинам и туркоманам. Во внешней политике ан-Насир Мухаммед перешел от обороны к экспансии. Вторжение монголов в 1312 г. в Сирию было неудачным и вскоре Хулагуиды пойшли на мир с мамлюками.

\footnotetext{
* A. E. Krımskiy, Ukrayna Doğu Bilimleri Fakültesi, bachman@meta.ua
} 
Отношения с Джучидами у ан-Насира Мухаммеда были прохладными. В то же время, мамлюки не считали зазорным оказывать поддержку пускай и не прямую противникам Хулагуидов - наместнику Тимурташу и грузинскому царю Гиорги V Блистательному. Излюблеными целями для набегов мамлюков были Киликийская Армения и Нубия. При Ан-Насире Мухаммеде был осуществлен целый ряд кампаний против Киликии. После его смерти они на время прекратились из-за внутренней борьбы в Мамлюкском султанате. Налеты киприотов и госпитальеров на побережье Ближнего Востока в 60-х гг. XIV в. обнажило слабость власти тюркских султанов и эмиров в Египте и Сирии. После анНасира Мухаммеда они могли одерживать победы над откровенно слабой Киликийской Арменией. Определенным эмирам удавалось захватить власть лишь на непродолжительное время. Наиболее видными эмирами этого времени были Кавсун, Йалбуга, Шайкун, Саргытмыш. Против власти мамлюков периодически восставали арабские бедуинские племена в Сирии и Египте. Необходимо отметить, что в борьбе между собой тюркские эмиры не брезговали пользоваться помощью бурджитских эмиров, также как Баркук не брезговал пользоваться помощью тюрских эмиров. Однако стоит отметить, что с 1382 г. в истории Мамлюкского султаната настал новый период в истории, когда Египтом и Сирией начала править черкесская династия.

Ключевые Слова: кыпчаки, ан-Насир Мухаммед, мамлюки, эмиры, Баркук, черкесы.

История кыпчаков за границами степи изучалась рядом исследователей. Нужно отметить, что история тюркских (кыпчакских) мамлюков найшла отображение в работах А. Кадырбаева, К. Цетерштеена и Р. Ирвина [4; 5, с. 547551; 18; 32]. Эпоха 1310-1382 гг. находиться в тени свершений Куттуза, Бейбарса и Калавуна. А. Кадырбаев и Р. Ирвин упоминали о правлении ан-Насира Мухаммеда бегло. Коренным образом от этого отличается книга А. Леванони, которая посвятила свою книгу третьему периоду правления этого султана [23]. Исследования по истории Киликийской Армении дают некоторые данные об отношениях с мамлюками в частности работ Г. Сукиасяна, Р. Бедросяна, Б. Дашдондонг и Л. Презбиндовски [6; 10; 12; 27]. Немного информации содержат работы связанные с историей Хулагуидов [28]. А. Атийа издал корреспонденцию между мамлюкскими султанами и арагонским королем, а А. Масия де Рос исследовала взаимоотношения Арагона с североафриканскими мусульманскими государствами [9; 24]. Важные данные касательно политики мамлюкских султанов относительно религиозных меншин есть в диссертации С. Паркера [26]. Б. АбуМанне посвятил статью истории грузин в Иерусалиме в эоху правления мамлюков, а Д. Лэнг посвятил статью истории правления грузинского царя Гиорги $\mathrm{V}$ Блистательного, где кратко говорилось о взаимоотношениях с Мамлюкским Египтом [8, р. 102-112; 22, р. 74-91]. Л. Де Мас Латри и П. Эдбёри исследовали историю Кипрского королевства и их отношений с мамлюками [13; 14, р. 90-105; 15]. Й. Ван Штеенберген исследовал отображение крестового похода 1365 г. в арабских источниках. Его перу также принадлежит статья о деятельности эмира Кавсуна. Д. Коробейников исследовал взаимоотношения Мамлюкского султана с Византийской империей [20, р. 53-74; 31, р. 123-126; 30, р. 449-466]. Проблемам взаимоотношений Мамлюкского Египта и Золотой Орды посвящены штудии С. Закирова и М. Фаверо-Думенжу [2; 7]. Задачей данного исследования являеться 
анализ главных тенденций в политической и социальной жизни кыпчаковмамлюков в 1310-1382 гг.

В 1310 г. ан-Насир Мухаммед пришел к власти после длительного периода вражды между мамлюкскими эмирами тюркского происхождения. В том году своей смертью умер Сайфр ад-Дин Кыбджак (Кыпчак) эмир Халеба. Бактимур ал-Джавкандар наиб Египта был арестован по приказу султана в 1311 г. Причиной этому было сместить султана и сделать султаном Алам ад-Дина Мусу. Султан перевел Карасункура из Дамаска в Халеб, сместив с поста наместника Халеба Асандамура, который был преемником Сайф ад-Дина Кыбджака. Карасункур в 1312 г. бежал к монголам Хулагуидам. Через некоторое время его примеру последовали еще несколько мамлюкских эмиров. На пост наиба Дамаска ан-Насир Мухаммед поставил Сайф ад-Дина Танкиза ал-Хусами, который правил регионом до самой смерти султана. В 1311 г. после ареста Бактимура наибом Египта на непродолжительное время стал Бейбарс алМансури. Вскоре на его пост назначили Аргуна ан-Насири, который был наибом в 1312-1317 гг. На место Карасункура в 1312 г. был назначен Ала ад-Дин Алтунбуга. В 1314-1317 гг. он был наибом Халеба. В 1317 г. он был переведен в Египет, а на его место назначили Аргуна, который правил Халебом до самой своей смерти в 1331 г. Начиная с 1311 г. султан ан-Насир начал укреплять свою власть. Он арестовал многих эмиров и в 1316 г. их казнил. Таки ад-Дин б. Амин ал-Мульк умер от самого страха преследований. Периодически ан-Насир Мухаммед устраивал репресии и после 1316 г. От пыток в 1339 г. умер ал-Нашу виновный в преследованиях коптов, в 1333 г. был арестован Алмас-хаджиб. В 1327 г. по приказу султана был возвышен Бахадур ад-Дамурдаши вместе со своим господином Дамурдашем б. Джубаном. Расположением султана пользовались Бактимур ас-Саки, Акбуга Абд ал-Вахид, Алтунбуга ал-Мардини. У ан-Насира Мухаммеда было 14 сыновей и 11 дочерей. Он хотел укрепить свою власть за счет династических союзов. Его старшие сыновья женились на дочерях Бактимура ас-Саки и Тукуздамура ал-Хамави. Дочери султана женились на Кавсуне, Баштаке и Абу Бакре (сыне Аргуна), то есть представителях мамлюковнасирийа. Количество этих мамлюков в 1315 г. составляло 2 тыс. Опорой султана также были дезертиры из войск Хулагуидов, монголы которые получили название в Египте вафидийа. Зависимость эмиров от султана усилилась. В 1320 г. как мамлюк в Триполи был куплен кыпчак Кавсун, который через некоторое время занял важное место среди мамлюков. Он получил мусульманское имя Сайфр адДин. Его родственники - дядя Туганджак и племянник Дукмак входили в состав наивысших сорока эмиров. Поднялся Кавсун на службе в Египте, а потом получил земли у Триполи. Другой видный в будущем деятель (полурусин-полукыпчак) Баштак попал как мамлюк непосредственно в Египет. В 1327 г. он уже был на должности эмира тысячи. В источниках упоминались его братья Тулутимур и Иван. Баштаку достались земли Бактимура ас-Саки. В элиту входили братья Бактимура ас-Саки Кумари и Айнабак, брат Айтамиша ал-Мухаммади ал-Хадж Аруктай, брат Аругна ан-Насири Манкалибуга ан-Насири, отец Йалбуги алЙахйави Табита, а также сыновья Табиты Асандамур и Каракиз. В 1337 г. Барсбугу ан-Насири султан назначил хаджибом, а в 1339 г. сделал его эмиром 
тысячи. Чин эмира тысячи получил Мугултай ал-Джалами. Ему был передан эмират Бахадура ал-Ибрагима. Ан-Насир Мухаммед также возвысил своих родственников. Так в Египте имели земли его дядя Таирбуга и его сыновья Закарийа и Йахйа. После смуты 1293-1309 гг. султан не доверял эмирам Калавуна и создавал элиту под себя [18, р. 105-109; 23, р. 28-40, 53-54; 17, р. 46].

Правитель перераспределял земельный фонд государства. Увеличились султанские владения ал-хасс, уменьшились фронды частных земель икта. Впрочем отобраные у одних эмиров земли он предоставлял своим султанским мамлюкам. Вертикаль власти пополнялась и за счет тех, кто не был мамлюками. Маликтимур ал-Хиджази, который стал при ан-Насире Мухаммеде эмиром тысячи прибыл в Египет из Багдада, оставив свою службу у фрилософра Усмана б. алСухраварди. В 1337 г. еще один человек из Багдада везирь Махмуд б. Али б. Ширван прибыл в Египет. Этот эмир (Ибн Ширван) стал один из сорока ведущих эмиров. Также в источниках упоминались Мухаммед б. ал-Сунна ал-Бусрави, Дамурдаш б. Джубан, Насир ад-Дин Халифа, Ахмад б. Бадлик ал-Туркумани. Комплектовались властные структуры и из сыновей мамлюков. Для них еще в XIII в. султаны учредили отдельное подразделение - мамлюки-халка. Девяносто три эмирских сына были эмирами сотни. Сыновья Айдугмыша получили эмираты за свою службу, как и Али б. Танкиз. Некоторые из них добивались значительных успехов. Мухаммед б. Тайбарс ал-Вазири командовал сирийскими войсками во время взятия армянского города Малатья в 1315 г. Три сына Бейбарса алХаджиба подавляли бунт шерифа Хумайда в Мекке в 1317 г. В 1332 г., совершая хадж в Мекку, султан мог быть спокойным по поводу того, что в Каире не поднимется восстание против него. Икта в первую очередь отдавались султанским мамлюкам. Однако спокойствие было обманчиво. Стоило ан-Насиру Мухаммеду отойти в иной мир как смуты возобновились. К тому же властный апарат снова раздулся до больших размеров в период с 1341 по 1382 гг. только одних эмирских сыновей было 257. Фонд султанских земель сокращался, возрастало могущество отдельных кланов. При этом часто их награждали без каких либо заслуг. Так, сын Йалбуги ал-Йахйави получил эмират будучи всего лишь семи лет отроду, сын наиба Дамаска Аргуна ал-Камила был назначен эмиром сотни, а потом и стал эмиром тысячи в возрасте трех лет. Влиятельные патроны хотели заполнить ведущие посты свои родственниками и для них был важен не талант, а лояльность. Финансовыми делами султан ан-Насир Мухаммед назначил заведовать коптов. Диванами управляли копты обращенные в ислам. Из коптов происходил племянник Карим ад-Дин ал-Кабира Карим ад-Дин асСагир, который занял пост министра фринансов (назир ад-даула). Этим фрактом были недовольны арабы, которые подозревали коптов в измене и враждебности исламу. В 1321 и 1323 гг. в Александрии и Каире вспыхнули антикоптские выступления. Ан-Насир Мухаммед предоставил фринансовые привилегии венецианцам. Он также установил дипломатические отношения с королевством Арагон и предоставил привилегии каталонским торговцам. Инициатором этих отношений был король Хайме II. Он в 1314 г. отправил посольство к ан-Насиру Мухаммеду. Посол просил обеспечить безопасность пилигримам в Святую землю, свободу вероисповедания христианам в мамлюкских владениях, 
освободить христиан из плена у мамлюков. Султан освободил в 1315 г. христиан. В 1318 г. Хайме отправил еще одно посольство, где просил все также освободить из плена франков. В 1323 г. Ан-Насир Мухаммед в письме королю Хайме писал, что христиане в его земле живут спокойно и счастливо. Такие действия помогли мамлюкам обойти режим фринансовой блокады, которую хотело Папство установить против них. Торговое эмбарго нарушили пизанские и генуэзские торговцы, которые обходили его, торгуя при посредничестве Кипрского королевства с мамлюками в порте Латакия. Бывали в Египте и купцы из Флоренции и Марселя. Занять прочные позиции в Египте хотели генуэзцы. Впрочем это не отемняло репрессий против маронитов Ливана пребывающих в церковной унии с Римом. Мамлюки преследовали маронитов, не простив им событий 1303 г., когда те поддержали крестоносцев. Султан поддерживал связь с Туглукидским Делийским султанатом и Расулидским Йеменом. Были контакты и с африканскими странами и бедуинами. В 1325 г. в Каире побывал с визитом манса (царь) страны Мали Муса. Султан сумел договориться с арабскими племенами Барки, а также с Бану Мухана и Бану Фадл. Старшие сыновья султана Анук, Ибрахим и Ахмад получили воспитание у бедуинов живших у Карака. Туркоманы Сирии также были включены в систему власти султана. В 1313-1323 гг. же оседлое население было занято на строительстве канала между Александрией и Каиром. В Каире были построены кварталы Лук, Макс, Булак, а также два больших здания [18, р. 109-118; 23, p. 40-41, 44-52, 133-142, 148-155, 174-176; 3 , c. $141 ; 26$, p. $200-201,210-211,242 ; 17$, p. $46,50-51 ; 16$, p. 382].

После смерти ильхана Газана к власти в Иране пришел Ольджейту Худабанда. Он попытался заручиться помощью католического Запада. Он отправил вместе с Бар Саумой письма Филиппу Красивому и папе римському в которых призывал искорентить секту Магомета. Хулагуидское посольство кроме Рима и Парижа посетило и Лондон, однако европейские монархи прохладно встрелили планы священной войны. Немного ранее к католическим королям обращался армянский король Гетум из Корикоса, предлагая им напасть на Триполи. Идеи крестового не пользовались спросом. Тогда Хулагуиды найшли другую причину для войны. В 1312 г. мамлюк Шамс ад-Дин Карасункур привел войска ильхана Ольджейту в Сирию. Монголов возглавлял наместник Хамадана ал-Афрам. Однако хулагуидское войскл понесло большие потери при осаде арРахбы, кроме того оно ощупало проблемы с логистикой. В январе 1313 г. монголы сняли осаду с крепости и отойшли за Евфрат. Они были серьезно заняты на востоке. В 1313 г. Хулагуиды аннексировали Никедерийскую Орду и в январе 1314 г. чагатайское войско во главе с Кепеком вторглось в Хорасан. Чагатайские войска нанесли серьезное поражение войску гератского правителя и Хулагуидам прийшлось выручать своего вассала. Впрочем и никудерийцы вскоре повздорили с чагатаями. Хулагуиды вступили на стороне Йасавура-оглана в войну против чагатаев на Амударье. В 1316 г. Олджейту умер и его сменил Абу Саид.

При Абу Санде ведущую роль занимал эмир Чабан. В 1317 г. Абу Саид провозгласил себя суннитом и это лишило войны между мамлюками и монголами религиозного подтекста. Кроме того, Хулагуидам было мягко говоря не до 
завоеваний на Ближнем Востоке. В 1319 г. против Абу Саида в Мазандаране восстал Йасавур. Его поддержал Джучид Узбек направивший в Ширван свое войско. Около реки Куры золотоордынское войско было разбито. В 1325 г. Узбек сделал новую попытку вторжения, но был разбит и Чабан перенес войну на вражескую территорию. В 1326 г. Чобан воевал уже на восточнных границах против чагатаида Тармаширина. Чагатаи в битве у Газны были разбиты эмиром Хасаном сыном Чобана. В 1321 г. наместник Хулагуидов в Анатолии Тимурташ сын Чобана восстал против своего ильхана и отправил к мамлюкам Мадж адДина ас-Саллами. Нерсес Палиенц сообщал, что в том году Тимурташ вторгся в Киликию и начал ее опустошать. Но там он встретил достойный отпор со стороны армян и был вынужден уйти из страны. После него в Киликию пришел египетский султан с 40 тыс. войска и дошел до Айаса. Далее он захватил морскую крепость и тогда на помощь армянам прийшли киприоты, которые спасли часть армян на своих суднах. После окончания мамлюкского вторжения Папа Римский помог армянам деньгами и отстроены были Айас и другие города. В 1322 г. Мадж адДин ас-Саллами вместе с мамлюком монгольского происхождения Айтамишем ал-Мухаммади вернулся в Иран. В 1323 г. мамлюки договорились о мире с Хулагуидами. Мамлюки продолжали ожесточено воевать только с христианами. Нерсес Палиенц сообщал, что мамлюки снова прийшли в Киликию и армяне уступили мамлюкам Айас и поселение по ту сторону Джахуна. Хотя Киликийская Армения была вассалом Хулагуидов, но сюзерен не оказывал должной поддержки вассалу. В 1326 г. Айтамиш был отправлен во вторую свою миссию к Хулагуидам. В 1327 г. разбитый Тимурташ бежал в Египет и прибыл в Каир. В 1328 г. мамлюки и монголы по этому поводу обменялись посольствами. На султанат Хулагуиды старались действовать через мамлюков-вафидийа (мамлюкских эмиров монгольского происхождения), также суфиев-мигрантов из Ирака и Ирана. Подрывную работу в султанате вел Ибн ал-Таймийа. Мамлюкский султан был сюзереном шерифа священных городов Мекки и Медины. Претензии Хулагуидов и Расулидов на власть над Хиджазом была удачно отброшены. Так в 1333 г. Ан-Насир Мухаммед направив войска в Хиджаз ликвидировал кратковременую власть Хулагуидов над регионом. Недолго упоминался Абу Саид в хутбе. Но и мамлюки непрямо поддерживали противников монголов. Так грузинам позволили построить православный храм в Иерусалиме. Грузинский царь Гиорги V Блистательный пользуясь борьбой Чобанидов с ильханом АбуСаидом в 1329 г. изгнал монголов из своей страны. Впрочем это не означало спокойной жизни для грузин в мамлюкских владениях. 19 октября 1314 г. грузинский православный монах Николоз Двали был убит в Дамаске. Он бы первым грузином совершившим после долгого перерыва путешествие в Святую Землю. Вместе с ним мученическую смерть приняли местные мелькиты и православные. Наместник Сирии Ала ад-Дин Танкиз преслдовал мелькитов. Положение мелькитов в Египте было более легким, их там не преследовали и их прошения исполнялись местными эмирами. Копты пользовались защитой со стороны самого султана, однако это не всегда их спасало. Евреи в Палестине жили же в мире и спокойствие. Мамлюки утверждали свою власть в бассейне Красного моря. В 1315, 1322, 1331 гг. мамлюки совершили несколько походов в Йемен. Благодаря им мамлюки навязали свой сюзеренитет Йемену, правда 
Расулиды признавали его лишь время от времени. В 1329 г. в Верхнем Египте состоялся мятеж бедуинов, но он был успешно подавлен и султан назначил наместником региона Зулузая. В 1335 г. фактически исчез субъект международной политики который уравновешивал Мамлюкский султанат. Хулагуидский Иран после смерти Абу Саида погрузился в смуту из которой не вышел целым. На месте Хулагуидов появились государства Чобанидов и Джелаиридов, а также республика сербадаров. Прежние вассалы монголов в Фарсе, Кермане, Хорасане, Луристане, Гиляне обрели самостоятельность [18, р. $118-120$; 1 ; 27, p. 88 ; 23 , p. 181-182; 28 , s. $127-128,136-142$; 11, p. 402-405, $407-$ 417 ; 26, p. 196-197, 227-228, 235-236, 240-241, 272-276; 22, p. 74-91; 10, p. 143$145 ; 25 ; 16$, p. 381-382].

Отдельно стоит поговорить о отношениях Мамлюкского Египта с Золотой Ордой в это время. В 1314 г. Узбек информировал ан-Насира Мухаммеда о своем восшествии на престол. Султан послал хану поздравление. В 1315 г. он попросил себе невесту из Джучидов. Хан вынудил султана взять в долг у его купцов 27 тыс. динаров. В 1320 г. в Египет прибыло золотоордынское посольство из 3 тыс. человек. Сестра Узбека Тулунбай заключила брачный договор с султаном с калымом в 30 тыс. динаров. В 1321 г. султан заплатил еще 40 тыс. динаров. В то же время Абу Саид послал даров на 25 тыс. динаров. Узбек надеялся на совместное выступление ордынцев и мамлюков против Хулагуидов. Но султан не только не помог, но и предупредил ильхана Абу Саида о планах Узбека. В 1322 г. египетский посланик вернувшийся из Золотой Орды доносил султану о плохом отношении с ним со стороны ханского двора. Узбек так аргументировал свое неудолетворение. Султан и его приближеные плохо однеслись к шейху Нуману, который занимал видное положение в Золотой Орде. Нуман не смог учредить в Иерусалиме вакфр и посетить Хеврон. Хан также был недоволен, что султан не послал войска в Ирак. Узбеку не было позволено даже построить мечеть в Иерусалиме. Ан-Насир Мухаммед вел себя так по отношению к татарам, будто Узбек в его глазах не был равным по статусу правителем. По приказу Узбека тогла был убит генуэзец Сигурано Салваиго и забрал себе 60 тыс. динаров и товара на 40 тыс. динара, которые были подарены Сигурано Карим ад-Дином. После этого инцидента состоялся обмен посольствами в 1324-1325 гг. В Египет прибыли ордынские послы Мангуш и Урус, а в Золотую Орду отправились Сайфр ад-Дин Бакмыш аз-Захири и Бадр ад-Дин Абугудда ас-Салари. Татарских послов несмотря на инцидент с Сигурано одарили и отправили с ними Сайфр ад-Дина Утуджи и Карадемира. В 1327-1328 гг. султан развелся с Тулунбай и отдал ее замуж за своего эмира Сайф ад-Дина Манкалибугу. После смерти этого эмира Тулунбай стала женой Сусуна, а после смерти Сусуна - женой Умара б. Аргуна наместника султана. Тулунбай умерла в 1342 г. В 1328 г. прибыло новое посольство от татар. Вместе с ним вернулся Сайф ад-Дин Утуджи. Когда же послы Узбека отправились на родину, то вместе с ними султан отправил Сайфр ад-Дина Маджара б. Абгана и его дядю Билика. В 1329 г. мамлюкские послы вернулись. В 1332 г. прибыло очередное посольство от татар с дарами султану. Следующее джучидское посольство прибыло в 1334-1335 гг. В 1337 г. к Узбеку от мамлюков отбыл начальник почты эмир Сартактай. В 1338 г. в Египет прибыло 
большое татарское посольство. В 1339 г. послы вернулись в Золотую Орду. Султан отправил вместе с татарами Алам ад-Дина Сулеймана и Ладжина (Лачина) ал-Хамави. В 1340 г. в Египет прибыло золотоордынское посольство во главе с Уруктемиром, Абу-Бекром и Кутлуг-Ходжей. Это было последнее посольство от Узбека [2, с. 73-90; 7, с. 334-345; 5, с. 549-550; 19, р. 449-466]

Нужно сказать, что в Мамлюкском султанате даже при таком сильном правителе как Ан-Насир Мухаммед было далеко не спокойно. Ее осложняли мусульманские проповедники, которые не желали мирится с относительной веротерпимостью. В 1320 г. в Дамаске начал антихристианскую проповедь обращеный в ислам еврей Саид б. Хасан. Он говорил, что Аллах даровал правоверным власть над представителями других религий, в частности над христианами и евреями. Как доказательство этого говорилось, что мамлюки по воле Божьей побеждали Хулагуидов, а Газан обратился в ислам. В правлении коптского патриарха Йуанниса Ибн ал-Кадди копты столкнулись с враждебным отношением. В «Истории Патриархов» сообщалось, что в 1321 г. копты столкнулись со многими бедствиями. Копты подвергались преследованиям со стороны мусульман во всех частях Египта. Мусульмане нападали на дома, церкви, монастыри и села коптов. Услышав об этом султан был сильно рассержен. Он послал мамлюков восстановить порядок. Более двадцати четырех церквей было опустошено на протяжении одного дня на просторах от Александрии до Куса. Церковь ал-Муалакка мусульмане осадили. Ряд мамлюкских эмиров воспринимал беды христиан как божье наказание коптам за их гордость и взяточничество. В Каире были замучены два христианских монаха и тогда четырнадцать коптских монахов собрали христиан, чтобы отомстить мусульманам. Однако последние победили, а монахов мусульмане сожгли. Чтобы обуздать события султан направил войска в город, но там столкнулся с 20 тыс. враждебно настроеными мусульманами. Видя все это, султан постановил, что копты не могут одевать белые тюрбаны, а только синие. Им было запрещено ездить на конях, а только на мулах. Нарушителей предписаний со стороны коптов ждала смерть и конфискация имущества. Сам султан не горел желанием преследовать христиан, но был вынужден пойти навстречу пожеланиям уммы, поскольку не желал обострения противоречий с горожанами-арабами. Тюркские мамлюки хотя и были военным сословием, но они были каплей в море арабского населения. Однако радикализм исламских масс подстегивался проповедниками. Одним из них был отец салафизма Ибн Таймийа. По данным Нерсеса Кркаци 1335 г. был плохим временем для христиан Иерусалима, поскольку мусульмане их преследовали. Говорилось, что тогда безбожные измаелиты вторглись в Киликию. Причиной для вторжения было названо то, что армяне убили кади таджика (то есть мусульманина, термин таджик у армян обозначал мусульманин) в Айасе. Преследовали мусульмане армян, франков (католиков) и греков (православных). Хамес из Вероны вторил армянину. Он говорил, что когда он пребывал на Кипре в 1334 г. в Фамагусте туда прибыли беженцы-армяне из города Логазе, который как и иные армянские земли разорял султан. Англоирландец Симон Фитцсимон говорил, что встретил в Святой земле ренегатов, в том числе из бывших госпитальеров, которые были враждебно настроены к 
християнству. В «Истории Патриархов» назван один из главных виновников преследований христиан ал-Нашу. Коптский хронист высказывал удолетворение тем, что вконце-концов тот получил воздаяние от Господа за гонения на христиан. В 1328 г. копты обратились к султану с просьбой отстроить церковь Святой Варвары, которая была уничтожена в ходе волнений в городах. Когда копты отстроили церковь, то в нее ворвались мусульмане и надругались над ней уничтожив внутренее убранство и читая в ней Коран. Тогда для успокоения был отправлен отряд вали Каира эмира Алам ад-Дина Синджара ал-Хазина. Это было сделано по воле султана и Карим ад-Дина. Эмир захватил в плен мусульман находящихся в церкви. Но после ан-Насира Мухаммеда христиане в Мамлюкском султанате оказались полностью бесправны. Кроме того, реагировать на преследования христиан со стороны мусульман султана вынуждали и некоторые внешнеполитические обстоятельства. В 1325 г. эфиопский негус Амда-Сион пригрозил уничтожить мечети в своей стране, если султан должным образом не будет реагировать на разорения церквей и не будет защищать коптов. Также он грозил перекрыть Нил дамбами, что угрожало урожаю в Египте, поскольку бы Нил не получил бы достаточно воды и ила. Негус Невайа Кристос же воплотил угрозы в жизнь. Он арестовал всех мусульман в своей стране и выслал из своей страны египетские торговые караваны. Мамлюки обратились к коптскому патриарху и только после его вмешательства прежние отношения возобновились. Кроме того, блокада египетской торговли угрожала торговле коптского клана ал-Карими. После обращения Нубии в ислам Эфиопия оставалась единственным бастионом христианства в регионе. Мусульманские государства на Африканском роге были вассалами Эфиопии. Ожесточенные войны с сомалийскими племенами не давали эфиопам более активно помогать коптам и нубийцам-христианам. Впрочем в Ливане была община готовая, если католики возобновят активность, им помочь. В 1336 г. немецкий доминиканец Вильгельм Больдензеле указывал, что 20 тыс. маронитов, которые являються хорошими лучниками, ждут выступления крестоносцев чтобы сбросить мамлюкское иго. Еще один немец Людольф фон Зухем писал, что марониты живут в Ливане и ожидают прихода крестоносцев. В 1340 г. в Дамаске против мелькитов было выступление мусульманских радикалов. Людольф фрон Зухем отмечал, что король Дамаска предал преследованию и убил многих христиан в 1341 г. перед смертью султана Каира [26, p. 243-249, 253-255, 264-266, 270-271, 277-278, 282-284; 17, p. 82-84; 29 , p. 143-150]

В 1315 г. ан-Насир Мухаммед совершил удачный поход на Киликийскую Армению. Местный правитель был вынужден платить дань в двойной размере по сравнению с той данью которую Лачин наложил на Киликию в 1293 г. В 1320, 1322, 1335 и 1340 гг. были осуществлены кампании против армян. В 1322 г. мамлюки взяли ряд городов в Киликии. Мамлюки были из них изгнаны, но в 1323 г. мамлюки навязали армянам дань в 50 тыс. золотых дирхемов (1,2 млн. дирхемов). Армяне также отдавали половину пошлины взымаемой в Айасе. В 1332 г. мамлюки взяли Ийас (Айас). В 1337 г. мамлюки заняли и опустошили Сис - столицу армян. В 1335-1337 гг. был осуществлен ряд набегов. Но Киликийская Армения продержалась до 1375 г. Она опиралась на союз с Кипрским 
королевством и Орденом госпитальеров. В 1315-1316 гг. мамлюки вмешались во внутренюю борьбу в Нубийской Макурии. Ан-Насир Мухаммед сверг Карпнбеса и поставил новым нубийским царем Абдаллаха Баршанбу. Таким образом, в Нубии ислам стал государственной религией вместо христианства. Племянник нубийского короля Канз ад-Даула также был мусульманином. В 1323-1324 гг. Каранбас восстановил мвою власть и мамлюкам прийшлось осуществить новую кампанию в Нубию и править Муккурой поставили династию Бану ал-Канц. В 1365-1366 гг. мамлюкские силы состоящие преимущественно из арабов взяли Донголу. В святи с принятием ислама Нубия прекратила уплату джизьи мамлюкам. На юг сместились племена арабской бедуинской конфелдерации джубайма, такие как Бали, Джубам, Тайи. Они проникли в Дарфур и Центральную Африку. В 1340 г. ан-Насир Мухаммед заболел. Однако он еще успел отдать приказ, чтобы замучать эмира Танкиза правившего в Сирии. Также пал и эмир алНашу. В 1341 г. ан-Насир Мухаммед умер и Мамлюкский султанат снова погрузился в усобицы. Англо-ирландский монах, который совершил поездку в Святую землю говорил, что отдал христианам султан церковь Пещеры Святой Марии в 1323 г., а до того на протяжении трех лет он преследовал христиан. В результате преследований погибло много яковитов в Сирии. Протекцией султана пользовались только копты. А католики и яковиты могли быть преследуемы. В 1335 г. в Святой Земле побывал Хамес из Вероны, а в 1336-1341 гг. немец Людольф фон Зухем, который заметил в землях султана влияние арагонцев, итальянцев, ромеев и грузин. Он отметил тысячи христианских пленных. По мнению С. Паркера этими пленными могли быть армяне из Киликии. Николло де Погинбоси отмечал, что с 1320 по 1335 гг. мусульмане занимали церкви сирийских христиан и превращали их в мечети. Такой была судьба церкви и монастыря Святой Марии Магдалены. Яковиты были вынуждены переместиться в дома над церковью архангела Михаила [4, с. 110-111; 18, р. 120-121; 27, р. 100, $104 ; 6$; 26, p. 223-225, 360-361, 371-381; 17, p. 76-78; 16, p. 382-383; 21, p. 404].

На момент смерти султана на Ближнем Востоке было несколько могущественных эмиров. Таштимур ал-Бадри, Бадр ад-Дин Джанкали б. ал-Баба, Тукуздамур ан-Насири, Джамал ад-Дин Акуш ал-Ашрафри, Бахадур ал-Хиджази, Кавсун, Баштак. Борьба за власть продолжалась с 1341 по 1345 гг. Главными претендентами были Тукуздамур, который поддерживал ал-Мансура Абу Бакра, ас-Салиха Исмаила, ал-Камила Шабана (сыновей ан-Насира Мухаммеда), а также Баштак и Кавсун женатые на дочерях султана. Сначала Баштак арестовал Кавсуна и сделал султаном Ахмада. Но через два месяца наиб ас-салтана Абу Бакр и Тукуздамур помогли Кавсуну освободиться и свергли султана и Баштака. Кавсун смог заручиться поддержкой многих эмиров и вскоре уже Абу Бакру пришлось бежать в Верхний Египет. На престол был возведен ал-Ашраф Кучук. Пользуясь неразберихой в Египте Таштимур ал-Бадри эмир Халеба отказался повиноваться Кавсуну и его ставленику. Когда Кавсун двинул против него свои силы, то Таштимур, забрав с собой большую частью воинов региона Халеб, мигрировал в бейлик Эретна. Угрозой режиму Кавсуна оставался самый старший сын ан-Насира Мухаммеда Ахмад, который обосновался в Караке и который назначил командующим своих войск эмира Кутулубуга ал-Фахри. Алтунбуга ал- 
Хаджиб правитель Дамаска также выступил против Кавсуна. В Каире в поддержку Алтунбуги выступил Йалбуга ал-Йахьяви. Вследствие заговора эмиров Кавсун и ал-Ашраф Кучук был смещены и на трон взошел Ахмад под тронным именем анНасир и правил в 1342 г. Он не хотел быть марионеткой Таштимура, вернувшегося из Эретны в Египет, которого поддержал Кутлубуга ал-Фахри. Заручившись поддержкой иных эмиров Ахмад взял циталель Каира и арестовал Кавсуна. Сам султан перебрался в Карак в Сирии, чтобы быть далее от влиятельных эмиров и их заговоров. Там он был в безопасности и находился под защитой местных арабов-христиан. Карак был важным пунктом между Сирией, Египтом и Хиджазом. Однако Ахмад вскоре был смещен с престола и на его место эмиры назначили султаном его брата Исмаила, который принял тронное имя ал-Салих и правил в 1342-1345 гг. Во главе государства реально находились Аксункур ас-Салари и Аргун ал-Алаи. В 1344 г. они совершили рейд на Карак и захватили этот город. Ахмад был схвачен и казнен. Эту экспедицию на Карак финансировали персидские купцы. В 1345 г. султан Исмаил ас-Салих даровал торговые привилегии венецианцам. Арабские племена Бану Фадлаллах и Бану Абд аз-Захир заняли важные посты в государстве, также среди султанских мамлюков важную позицию занял Анбар ас-Сахрати. В августе Исмаил ас-Салих умер, что означало очередной передел власти. На первый план вышел до того маловлиятельный Аргун ал-Алаи сделавший султаном ал-Камила Шабана. В опозиции Аргуну находился министр финансов Гурлу. В 1346 г. против ал-Камила Шабана выступил наиб Дамаска Йалбуга ал-Йахйави. В сентябре 1346 г. он провозгласил Хаджи султаном под именем ал-Музаффар. Йалбугу поддержали Маликтимур ал-Хиджази и египетские эмиры. По приказу султана, Гурлу начал массовую закупку черкесских рабов. Против этого выступил наиб ас-салтана Ариктай ал-Насири. Вследствие восстания Гурлу и Хаджи ал-Музаффрар были убиты. Султаном стал ал-Малик ан-Насир Хасан (еще один сын ан-Насира Мухаммеда). Реально правил триумвират эмиров - наиб Байбуга ал-Арус, визир Манджак ал-Йусуфи и эмир Таз ан-Насири. В 1347-1349 гг. эпидемия бубонной чумы поразила земли султаната. Египет и Сирия потеряли до трети своего населения. Войско также было серьезно ослаблено. И позже циклично чума возвращалась в Египет. В 1348 г. наиб Триполи арестовал наиба Дамаска Аргуншаха. Черкесские мамлюки в 1347 г. попробывали захватить власть, но тюркские мамлюки объединились против них и подавили их выступление. В 1348 г. бедуинские племена Бану Нумайр и Бану Рабийа из окрестностей Карака нанесли мамлюкам тяжелое поражение. Между 1343 и 1353 гг. бедуинские племена Верхнего Египта воевали между собой. В 1346 г. мамлюки взяли армянский город Айас и поставили его под свой контроль [18, р. 125-139; 23, р. $118-119,180-183,186 ; 26$, p. 320; 16, p.389].

После смерти ан-Насира Мухаммеда усилились гонения на христиан. В 1352-1354 и 1365 гг. мамлюкские власти преследовали коптов в Каире. Султан Хасан в 1349 г. приказывал бедуинам не преследовать христиан, значит прецеденты религиозных гонений в эпоху смуты уже были. При этом нужно иметь в виду, что мелькиты запросили помощи Папы Римского для защиты своих прав. Христиане обращались с петициями о защите своих прав в 1347 г. к султану 
Хаджи, в 1348-1349 гг. - к султану Хасану, в 1352-1354 гг. -к султану ал-Салиху Салиху. Центр Антиохийского патриархата был перемещен в 60-х XIV в. из Антиохии в Дамаск. Это было обусловлено тем, что мамлюки боялись, что сирийские христиане будут помогать кирпиотским католикам в их набегах на побережье Восточного Средиземноморья. Боясь гонений арабов, спровоцированых налетами католиков, патриарх Иерусалима Лазарь бежал в Константинополь. Особенно от мусульман досталось маронитам в 1365-1367 гг. Их патриарх Джибраил Хаджула умер мученической смертью в 1367 г. Даже грузины в 40-х гг. XIV в. ощутили преследования со стороны мамлюков. Султан ал-Музафффар хаджи был вынужден в 1346 г. взять их под свою защиту. В 1343 г. мамлюки опустошили армянское гетто в Каире. В «Житии коптского Святого Маркуса ал-Антуни» отмечал, что после того как франки разорили Александрию, эмир Йалбуга отправил своих людей грабить монастыри и угнетать христиан Египта. Армянский хронист Вардан Лримеци отмечал, что в 1366 г. фрранки взяли пленных в Александрии и султан, узнав об этом, приказал арестовывать всех христиан и бросить их в темницу, а также жестоко обращаться с ними и обыскивать их дома. Был захвачен в плен даже негус эфиопов (он тогда совершал паломничество по святым местам) вместе со своими людьми и был отправлен в Иерусалим [26, р. 323-343, 346-354]

В 1351 г. усобицы разгорелись с новой силой. Когда Байбуга удалился в хадж Таз, сговоришись с Саргитмишем, захватил власть в Египте. Байбугу арестовали в Хиджазе, а Манджак был взят в плен в Каире. На престол был возведен ас-Салих Салих, еще один сын ан-Насира Мухаммеда. Он пользовался поддержкой среди сирийских эмиров. В 1352 г. Байбуга поднял восстание. Он воспользовался помощью туркоманов Зулькадира. Его поддержали мамлюки Халеба и Триполи, арабы-бедуины племени Бану Фадл. Эмир Зулькадира Караджа опустошил Дамаск и лишь номинально подчинялся Байбуге. Вскоре он предал своего союзника. Караджу, в свою очередь, предал Махмуд б. Ала ад-Дин Эретна. Турецкий бейлик Эретна еще при отце Махмуда сбросил с себя зависимость от монголов. В Верхнем Египте с 40-х гг. XIV вв. власть взяли шейхи кочевых бедуинских арабских племен и султанам с большим трудом удавалось удерживать этот регион в сфере своего влияния. Мамлюкские гарнизоны находились в Кусе и других ключевых городах края. Наместником края был назначен Тугай. Далее мамлюкская власть не простиралась. В 1351 г. восстали бедуины Верхнего Египта, которых возглавил Мухаммед б. Васил ал-Адаб шейх племени арак. В 1353-1354 гг. эмиру Шайкуну прийшлось совершить большой поход в Верхний Египет совместно с бедуинами Йамани. Местные бедуины Кайси были вынуждены стать лояльными к каирской власти. В самом Египте в 1351 г. к власти пришел Алам ад-Дин б. Зунбур. Он был везирем и оставил номинально править свою марионетку ал-Салиха Салиха. Сам Ибн Зунбур был из принявших ислам коптов. Его поддерживал Шайкун, который был заклятым врагом Саргытмыша. В 1352 г. Ибн Зунбур был смещен и был изгнан в Кус, где умер в 1353 г. В 1354 г. Саргатмыш спровоцировал восстание мусульман против криптохристиан из бывших коптов. В том году образовался триумвират Саргытмыша, Шайкуна и Таза. Вскоре он распался, когда Таз был в Верхнем Египте, 
Саргытмыш перебил людей Таза в Каирской цитадели. Султаном сделали анНасира Хасана. Саргытмыш и Шайкун вынуждено терпели друг друга до 1357 г. Люди Саргытмыша убили перед самим султаном Шайкуна в 1357 г., а сам султан расправился с Саргатмышем в 1358 г. силами султанских мамлюков во главе которых стоял Йалбуга ал-Хассаки. Йалбуга был убит в 1366 г. В 1361 г. против Йалбуги выступили сирийские эмиры во главе с Байдамуром наибом Дамаска. Тогда Йалбуга сверг ан-Насира Хасана и сделал султаном сына ал-Музаффрара Хаджи ал-Мансура Мухаммеда. В 1363 г. этот султан был возвращен в гарем и на престол был поставлен малолетний сын ан-Насира Хасана ал-Ашраф Шабан. С 1361 по 1366 гг. Йалбуга именовал себя титулом атабак ал-асакир. Кризис Мамлюкского султаната начал сказываться на внешней политике. Хотя в 1355 г. мамлюки заняли Тарс, Адану и Масису, но они не смогли покорить Киликийскую Армению. Пираты из королевства Кипр и госпитальеры из Родоса совершали пиратские рейды. Для войны с армянами мамлюки войшли в союз с бейликами Караман и Зулькадыр. Йалбуга открыл для венецианцев порт Бейрут для торговли, как раньше был открыт для торговли порт Александрии. В 1354 г. пиратский христианский корабль напал на мусульманские судна около Александрии. Капитан корабля донес, что Александрия плохо охраняется. Следующий рейд на Розетту свидетельствовал, что и побережье Египта плохо защищеною. В 1360 г. киприоты заняли армянский порт Корикос, а в 1361 г. отняли Адалью у бейлика Текке. В 1363 г. три киприотские галлеи взяли много мусульман в плен. Потом шесть галлей грабили побережье у Александрии и Розетты. После стольких рейдов Пьер I Лузиньян убедился, что рейд на Александрию будет легким. В союзе с венецианцами он напал в 1365 г. на Египет. На наличие венецианцев указывал ал-Макризи. 10 октября не встречая заметного сопротивления крестоносцы взяли Александрию. В экспедиции приняли участие и венецианцы. Киприоты и их союзники также совершили налеты на Триполи, Сидон, Латакию, Тортосу, Бейрут. Также крестоносцы нападали и на армянские порты Айас и Бодрум. Рейды крестоносцев обнажили слабость кыпчакских мамлюков и киликийских армян. Йалбуга не проявил должной реакции в 1365 г. и позволил киприотам грабить дельту Нила. Армяне не смогли перейти в контрнаступление только из-за того, что в их собственной стране бушевали усобицы. Между собой боролись сторонники династии Лузиньянов и их противники. Киликийская Армения была разделена и по религиозному признаку. Армяно-католики враждовали со сторонниками Армянской Апостольской церкви. В 1369 г. же армяне приняли унизительные требования со стороны мамлюков. В 1375 г. мамлюки совершили вторжение в Киликию. Сначала пал Айас. Потом мамлюки и турки взяли Адану, Тарс и Корикос. В апреле 1375 г. пал город Сис. Киликийская Армения была разделена между мамлюками и туркоманами вассального бейлика Рамадан. Армянский царь Левон VI Лузиньян вместе с семьей был взят в плен и доставлен в Египет. Правда армянский барон Константин продолжал удерживать ряд регионов Киликии под своим контролем до 1424 г. Йалбуга начал строить фрот фурусийа для того, чтобы противостоять крестоносцам, однако в 1366 г. был убит собственными эмирами. После его смерти страной реально управляли Таштимур, Йалбуга ал-Йалбугави, Каратай, Барка и Баркук. Султаном же был провозглашен 
ал-Ашраф Шабан. В 1368 г. арабские бедуинские племена Бану Фадл и Бану Килаб убили наиба региона Халеб и разорили его территории. В 70-х гг. XIV в. туркоманы Зулкадира разоряли северные границы региона Халеб. В 1374-1375 гг. Египет снова ощутил угрозу со стороны соседей. В 1377 г. ал-Ашраф Шабан планировал отправиться в хадж, однако в марте 1377 г. он был захвачен своими эмирами в каирской цитадели. Власть в Египте захватил Баркук мамлюк черкесского происхождения, В Сирии доминировал наиб Дамаска тюрок Таштимур ал-Алаи союзником которого был Барка [18, р. 139-149; 27, р. 56-57, 100,$104 ; 6 ; 23$, p. $119-122,183-184,186 ; 3$, c. $142 ; 26$, p. $321-323 ; 17$, p. $51 ; 14$, p. $90-105 ; 31$, p. $123-136 ; 13$, p. 273-280, 286-288; 16, p. 389-390].

В 1382 г. Баркук разделался с своими тюркскими конкурентами, воссоединив Сирию с Египтом. Официально правителем мамлюкского султаната Баркук стал в 1382 г. когда умер султан ал-Мансур Али. Его конкурентом также был последний тюркский султан ал-Салих Хаджи II, который смог в 1389 г. на недолгое время вернуть себе трон. Против Баркука поднял восстание Йалбуга ан-Насири в 1388 г. Подавить восстание он смог наградив Джулбана алКумушбугави аз-Захири, назначив его эмиром Халеба. Опозицию Баркуку составляли бедуины в Сирии в 1394 г. и Али-бай в Египте в 1397 г., а также Минташ в 80-х гг. XIV в. В 1389 г. когда Баркук вернул себе власть, то тюрок Акбуга Тулутамури аз-Захири встал на службу черкесу. Причиной восстаний было еще то, что султан хотел реформировать государство. Отвыкшие от сильной руки мамлюки и их подданые естественно некоторое время сопротивлялись этому. Баркук принял тронное имя аз-Захир. Воцарение Баркука обозначало начало нового периода в истории Мамлюкского султаната. Тюрки перестали играть сколько-нибудь значимую роль, а основную массу мамлюков составляли бурджиты - мамлюки черкесского и грузинского происхождения [18, p. 152, 158; 23, p. $96-98,117 ; 17$, p. 53; 16, p. 390-391].

Нужно отметить, что после смерти ан-Насира Мухаммеда тюркские мамлюки продолжали отношения с Золотой Ордой. Правда им было дадлеко до прежней интенсивности. В 1342-1343 гг. В Египет прибыло посол от хана Джанибека Кара-Бахадур. Активный обмен посольствами между мамлюками и Золотой Ордой был прерван эпидемией бубонной чумы. В 1357 г. прибыло второе посольство от Джанибека, хан сообщил султану о победе над Маликом ал-Ашрафом и доставило мамлюкам подарки. Султан ал-Малик ан-Насир Хасан предлагал татарам возобновить дружбу. В 1374-1375 гг. секретарь египетского султана ал-Мухибби написал письмо золотоордынскому хану Мухаммеду по прозвищу Урус. В 1380 г. в Египет прибыло посольство от Токтамыша. В 13841385 гг. посольство Токтамыша прибыло уже к черкесским мамлюкам. Ответное посольство мамлюков прибыло в Золотую Орду в 1386-1387 гг. Далее Токтамыш дружил с мамлюками против великого эмира Тимура [2, с. 90-94; 16, р. 391].

Таким образом, мы прийшли к следующим выводам. Прийдя к власти анНасир Мухаммед занялся перестройкой властной вертикали в 1310-1316 гг. Эмиры замешаные в смуте 1293-1310 гг. были или физически устранены или бежали в сопредельные государства. Эмиры эпохи Калавуна были заменены ставленниками ан-Насира Мухаммеда. Периодически султан репрессировал 
чрезмернно усилявшихся эмиров. Султан расширял обогащал свою страну за счет торговли с европейцами и за счет ведения финансовых дел коптами. Некоторые привилегии достались и арабам-бедуинам и туркоманам. Во внешней политике ан-Насир Мухаммед перешел от обороны к экспансии. Вторжение монголов в 1312 г. в Сирию было неудачным и вскоре Хулагуиды пойшли на мир с мамлюками. Отношения с Джучидами у ан-Насира Мухаммеда были прохладными. В то же время, мамлюки не считали зазорным оказывать поддержку пускай и не прямую противникам Хулагуидов - наместнику Тимурташу и грузинскому царю Гиорги V Блистательному. Излюблеными целями для набегов мамлюков были Киликийская Армения и Нубия. При Ан-Насире Мухаммеде был осуществлен целый ряд кампаний против Киликии. После его смерти они на время прекратились из-за внутренней борьбы в Мамлюкском султанате. Налеты киприотов и госпитальеров на побережье Ближнего Востока в 60-х гг. XIV в. обнажило слабость власти тюркских султанов и эмиров в Египте и Сирии. После ан-Насира Мухаммеда они могли одерживать победы над откровенно слабой Киликийской Арменией. Определенным эмирам удавалось захватить власть лишь на непродолжительное время. Наиболее видными эмирами этого времени были Кавсун, Йалбуга, Шайкун, Саргытмыш. Против власти мамлюков периодически восставали арабские бедуинские племена в Сирии и Египте. Необходимо отметить, что в борьбе между собой тюркские эмиры не брезговали пользоваться помощью бурджитских эмиров, также как Баркук не брезговал пользоваться помощью тюрских эмиров. Однако стоит отметить, что с 1382 г. в истории Мамлюкского султаната настал новый период в истории, когда Египтом и Сирией начала править черкесская династия.

\section{LITERATURA}

ABU-MANNEH (1984), B. The Georgians in Jerusalem in the Mamlūk Period // Egypt and Palestine: a Millennium of Association (868-1948). Jerusalem : Ben-Zvi Institute for the Study of Jewish Communities in the East - New York : St. Martin's Press, p. 102-112.

Armänskie istoçniki o mongolah (1960), (İzvleçeniä iz rukopisey XIII—XIV vv.) / Perevod s drevnearmänskogo, predisl. i prim. A. G. Galstäna. M.: Vostoçnaä literatura, 1962. 154 s. http://www.vostlit.info/Texts/rus9/Palienz/frametext.htm

ATIYA A. S. (1938), Egypt and Aragon: Embassies and Diplomatic Correspondence between 1300 and 1330 A.D. Leipzig: F.A. Brockhaus, 8, 73 p.

BEDROSIAN R. (1979), The Turco-Mongol Invasions and the Lords of Armenia in the 13-14th Centuries. PhD Thesis. New-York: Columbia University, 1979. http://rbedrosian.com/Mongols/TMILA.pdf

BOYLE J.A.(1968), Dynastic and political history of II-khans // The Cambridge history of Iran. Vol.5. Saljuk and Mongol period. Cambridge: Cambridge university press, 1968. p. 303-421. 
DASHDONDOG B. (2011), The Mongols and the Armenians (1220-1335). Leiden: E.J. Brill, 267 p.

DE MAS LATRIE L. (1852), Histoire de l'île de Chypre sous les princes de la maison de Lusignan. Vol. II. Paris: A L'Imprimerie nationale, 1852. https://books.google.com.ua/books?id=kdsGAAAAQAAJ\&printsec=frontcover\&hl=uk\&s ource $=g b s$ ge summary $r \& c a d=0 \# v=$ onepage \&q\&f=false

EDBURY P. (1977), The Crusading Policy of King Peter I of Cyprus, 1359-1369 // The Eastern Mediterranean Lands in the Periods of the Crusades. Warminster, P. 90105

EDBURY P.(1991), The Kingdom of Cyprus and the Crusades, 1191-1374. Cambridge: Cambridge university Press, $256 \mathrm{p}$.

FAVERO-Dumenju (2016), M. Zolotaä Orda i mamlüki // Zolotaä Orda v mirovoy istorii. Kazanı: İnstitut istorii im. Ş. Marcani, S. 334-353

GARCIN J. C. (1984), Egypt and the Muslim world // General History of Africa Volume IV - Africa from the Twelfth to the Sixteenth Century. Berkeley: UNESCO Publishing, P. 371-397

HRBEK I. (2007), Egypet, Nubia and Eastern desert // The Cambridge history of Africa. Vol. 3. From c. 1050 to c. 1600 . Cambridge: Cambridge university press, p. 1097

IRWIN R. (1986), The Middle East in the Middle Ages: the early Mamluk Sultanate 1250-1382. London: Croom Helm, 180 p.

KADIRBAEV A.Ş (1997), . Za predelami Velikoy stepi. Almatl: Demeu, 1997. $198 \mathrm{s.}$

KADIRBAEV A.Ş. (2017), Zolotaä Orda i Mamlükskiy Egipet: politiçeskie i kulıturrnle sväzi // İstoriä tatar. T. 3. Ulus Cuçi (Zolotaä Orda). XIII - seredina XV v. Kazanı, İnstitut istorii im. Ş. Marcani, S. 547-551

KEDAR B. (1976), Segurano-Sakrān Salvaygo: un mercante Genovese al servizio dei Sultani Mamalucchi, c. 1303-1322 // Fatti e idée di storia economica nei secoli XIIXX. Studi dedicati a Franco Borlandi. Bologna: Società editrice il Mulino, P. 75-91.

KOROBEINIKOV D.A. (2004), Diplomatic Correspondence between Byzantium and the Mamlūk Sultanate in the Fourteenth Century // al-Masāq. Vol. 16. Issue 1. Leeds: Department of Modern Arabic Studies, University of Leeds, P. 53-74

KROPAČEK L. (1984), Nubia from the late $12^{\text {th }}$ century to the Funj conquest in the early $15^{\text {th }}$ century // General History of Africa - Volume IV - Africa from the Twelfth to the Sixteenth Century. Berkeley: UNESCO Publishing, P. 398-422

LANG D.M. (1955), Georgia in the Reign of Giorgi the Brilliant (1314-1346) // Bulletin of School of Oriental and African Studies. Vol. 17. London: University of London, 1955. p. 74-91

LEVANONI A. A (1995), Turning point in Mamluk history: the third reign of al-Nasir Muhammad ibn Kalawun (1310-1341). Leiden-New York-Koln: Brill, IX, 221 p. 
MASIÀ de Ros (1951), A. La corona de Aragón y los estados del norte de Africa: politica de Jaime II y Alfonso IV en Egipto, Ifriqúia y Tremecén. Barcelona: Ed. Instituto Español de Estudios Mediterráneos, $518 \mathrm{p}$.

MELVILLE Ch.(1999), The Fall of Amir Chupan and the Decline of the Ilkhanate, 1327-37: A decade of discord in Mongol Iran. Bloomington: Indiana University research institute for Inner Asia Studies, $90 \mathrm{p}$.

PARKER S. (2012) The Indigenous Christians of the Arabic Middle East in an Age of Crusaders, Mongols, and Mamlūks (1244-1366) // Thesis Submitted for the Doctorate of Philosophy under theSupervision of Professor Jonathan Harris. London: Royal Holloway College, University of London, https://www.academia.edu/2643175/The Indigenous Christians of the Arabic Middle East in an Age of Crusaders Mongols and Maml\%C5\%ABks 1244-1366

PREZBINDOWSKI L. (2012), The Ilkhanid Mongols, the Christian Armenians, and the Islamic Mamluks : a study of their relations, 1220-1335. A Thesis Submitted to the Faculty of the College of Arts and Sciences of the University of Louisville in Partial Fulfillment of the Requirements for the Degree of Master of Arts Department of History.

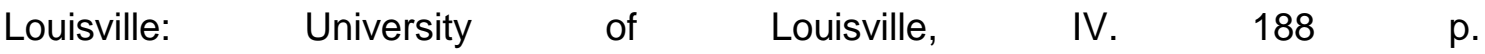
http://ir.library.louisville.edu/cgi/viewcontent.cgi?article=2151\&context=etd

SPULER B. (1952), İran Moğolları. Ankara: Turk Tarihi Kurumu Basimevi, 1952. 554 S.

SUKIASÄN A.G. (1969), İstoriä Kilikiyskogo Armänskogo gosudarstva i prava (HIXIV Vv.). Erevan: İdatelıstvo «Mitk», 333 s. http://www.armenianhouse.org/suqiasyan/cilicia/1.html\#2

TAMRAT T. (2007), The Ethiopia, the Red sea and the Horn // The Cambridge history of Africa. Vol. 3. From c. 1050 to c. 1600. Cambridge: Cambridge university press, 2007. p. 98-182

VAN Steenbergen J. (2001), The Amir Qawsūn, Statesman or Courtier? (720-741 $\mathrm{AH} / 13201341$ AD) // Egypt and Syria in the Fatimid, Ayyubid and Mamluk eras. Leuven: Peeters Publishers, 2001. P. 449-466.

VAN Steenbergen J.(2003), The Alexandrian Crusade (1365) and the Mamlūk Sources // East and West in the Crusader States III. Leuven: Peeters Publishers, p. 123-136.

ZAKIROV S.Z. (1966), Diplomatiçeskie vzaimootnoşeniä Zolotoy Ordl s Egiptom (XIII-XIV vv.). M.: Nauka, 161 c.

ZELENEV E.İ. (1999), Egipet: Srednie Veka. Novoe vremä. SPb.: İzd-vo SanktPeterburgskogo Universiteta, 1999. $340 \mathrm{~s}$.

ZETTERSTÉEN K.V.(1919), Beiträge zur Geschichte der Mamlūkensultane in den Jahren 690-741 der Hiǵra, nach arabischen Handschriften. Leiden: E.J. Brill, 1919. $\mathrm{XVI}, 120 \mathrm{p}$. 